\title{
Factors Associated with Umbilical Cord Stump Healing Practices: Literature Review
}

\author{
Marilya Rodrigues Reis', Marília Cordeiro de Sousa1, Lays de Souza Silva1, \\ Lívia Roberta Rodrigues Conceiçãoํㅜ, Marcela de Andrade Silvestre ${ }^{1}$, \\ Camila de Pina Soares Sudário', Renata Calciolari Rossi², Janaína Valadares Guimarães', \\ Thaíla Corrêa Castral'1, Karina Machado Siqueira1', Pedro Teixeira Meireles ${ }^{3}$, \\ Bruno Belmonte Martineli Gomes ${ }^{4}$, George Kemil Abdalla ${ }^{5}$, Douglas Reis Abdalla5, \\ Ana Karina Marques Salge1
}

${ }^{1}$ Faculty of Nursing, Federal University of Goiás, Goiânia, Brazil

${ }^{2}$ UNIOESTE, Presidente Prudente, Brazil

${ }^{3}$ Medicine Course, University of Uberaba, Uberaba, MG, Brazil

${ }^{4}$ Biomedicine, University of São Paulo, Ribeirão Preto, Brazil

${ }^{5}$ Health Sciences, Faculty of Human Talents, Uberaba, Brazil

Email: drabdalla@facthus.edu.br

How to cite this paper: Reis, M.R., de Sousa, M.C., Silva, L. de S., Conceição, L.R.R., Silvestre, M. de A., Sudário, C. de P.S., Rossi, R.C., Guimarães, J.V., Castral, T.C., Siqueira, K.M., Meireles, P.T., Gomes, B.B.M., Abdalla, G.K., Abdalla, D.R. and Salge, A.K.M. (2020) Factors Associated with Umbilical Cord Stump Healing Practices: Literature Review. Open Journal of Obstetrics and Gynecology, 10, 1067-1078 https://doi.org/10.4236/ojog.2020.1080100

Received: March 19, 2020

Accepted: August 18, 2020

Published: August 21, 2020

Copyright $\odot 2020$ by author(s) and Scientific Research Publishing Inc. This work is licensed under the Creative Commons Attribution International License (CC BY 4.0).

http://creativecommons.org/licenses/by/4.0/ (c) (i) Open Access

\begin{abstract}
Objective: To analyze the evidence in the evolution of scientific production on the factors associated with curative practices of the umbilical stump. Materials and Methods: The study data collection took place in April 2017. The electronic databases used to search the articles were: PubMed (National Library of Medicine and National Institutes of Health) and VHL (Virtual Health Library). We used the keywords "perinatal care", "umbilical cord", "patient care team", "neonatology", "newborn", in the Portuguese, English and Spanish languages, accompanied by the expression AND and selected through DeCS (Descriptors in Health Sciences). Results: A final sample of 9 articles was obtained from the PubMed and VHL databases, which met the inclusions criteria. It has been found that traditional umbilical stump care practices are still present in many communities, however, have been replaced by appropriate practices, the most recommended being: chlorhexidine $4 \%$ sanitation, soap and water and alcohol antisepsis $70 \%$. Conclusions: There is a need for multi-professional involvement, approaching these women since pregnancy, with detailed information and accessible language about proper care with the newborn and the umbilical stump.
\end{abstract}

\section{Keywords}

Perinatal Care, The Umbilical Cord, Patient Care Team, Neonatology, Newborn 


\section{Introduction}

Approximately 3.3 million neonatal deaths occur annually worldwide [1]. Of these, about half a million newborns die each year from severe neonatal infections, representing $15 \%$ of the etiology of neonatal deaths [2]. Additionally, most of these deaths occur outside hospital units and may be related to inadequate hygiene practices [3], especially in the umbilical stump region.

A wide variety of cultural beliefs and practices are associated with healing practices of the umbilical stump, such as applying ashes, oils, butter, spice paste, herbs, mud, and animal lard. These substances that are frequently contaminated with spores and bacteria, so the use of them associated with the presence of newborn skin colonization by pathogenic bacteria increase the risk of infection [4] [5] [6] [7].

In the area of the umbilical stump there is the growth of some beneficial microorganisms and others that are harmful, like Clostridium tetani. This microorganism causes omphalitis, umbilical stump infection, that can evolve to sepsis neonatal, after contact with the bloodstream [8] [9] [10]. The incidence on omphalitis in low-income countries is still scarce, but it is estimated that the risk may range from 2 to 77 per 1000 live births in hospitals whose mortality rate varies from $1 \%$ to $15 \%$ [11].

The symptomatology of newborns with the diagnosis of neonatal tetanus is associated with tonic contractions of the chewing muscles, such as dysphagia and trismus [12] [13] [14] [15]. Despite the high mortality rate due to neonatal tetanus, studies show a significant decline in morbidity and mortality in recent years [16] [17].

Currently, the recommended practice in the treatment of umbilical stump is hygiene with soap and water and antisepsis with 70\% alcohol [18] [19]. The postpartum woman is oriented in the proper way to care for the umbilical stump with this substance; however, the influence of the social group in which she is inserted is so strong that it creates doubts between the old and the new orientations [20].

Considering the importance of the social and cultural environment in which the puerperal is inserted as a determinant in its curative practice with the newborn, the importance of interventions that include these spheres in its health education strategies is highlighted. Thus, there may be behavioral changes in the care provided to newborns in order to reduce neonatal mortality rates, as well as harmful practices such as the use of inappropriate materials for umbilical stump dressing [21].

So, promoting good healing practices should involve guidance from health professionals to mothers about correct practices. Action requires professional scientific knowledge to support newborn care [6] [18] [19]. Ensuring the success of the guidelines is extremely important, for this, the professional must investigate whether the mothers and their families have assimilated the information received and have the ability to perform the care autonomously and assertively [22]. 
Considering all the responsibilities imposed on the caregiver, this study aims to analyze the evidence in the evolution of scientific production on the factors associated with curative practices of the umbilical stump.

\section{Materials and Methods}

This is an integrative literature review, whose purpose is to synthesize knowledge and results of previous research on a given subject in a systematic and organized manner, to incorporate evidence into practice, enable the construction and elaboration of effective interventions in health care [23].

An integrative literature review is conducted in 6 methodological steps. The first step consists in elaborating the hypothesis, that is, identify the search problem, the search engine that will be adopted and determinate which descriptors or search keywords will be used. The second stage included establishing the inclusion and exclusion criteria of the articles to be selected for sample composition. In the third stage, through the exploratory reading of the abstracts, a pre-selection of the studies is performed. In the fourth stage, analytical reading of the studies is performed in order to gather, analyze and categorize the pertinent information to the investigated problem. The fifth stage comprises the interpretation of the results. The sixth and last stage promotes the synthesis and presentation of the results identified as recommendations for further studies [24] [25].

Using this protocol that has been described, the guiding question of this integrative review was: What is the evidence in the evolution of scientific production about the factors associated with the curative practices of the umbilical stump? After defined this, the study data collection took place in April 2017. As electronic database used to search for articles: PubMed (National Library of Medicine and National Institutes of Health) and VHL (Virtual Health Library). The keywords "perinatal care", "umbilical cord", "patient care team", "neonatology", "newborn" in the Portuguese, English and Spanish languages, accompanied by the expression AND were used. The descriptors used were selected through DeCS (Descriptors in Health Sciences), available from the VHL. For the selection, the following inclusion criteria were selected: centralized use as curative practices of the umbilical stump, articles based on scientific research, original research and case report, written in Portuguese, English and Spanish with full text available online, production published from 2011 to 2017.

Following the location and selection of articles, 815 potentially eligible publications to be included in this review were identified. With the removal of articles that did not meet the inclusion criteria $(\mathrm{n}=555)$ and those by duplicity $(\mathrm{n}=$ 118), the abstracts of 142 articles were analyzed. After reading the abstracts, 100 articles were excluded, and the full reading of 42 articles resulting in the selection of 9 articles met the inclusion criteria and answered the review question (Figure 1).

\section{Results}

In the time limit set for this study (2011-2017), 9 publications were found and 


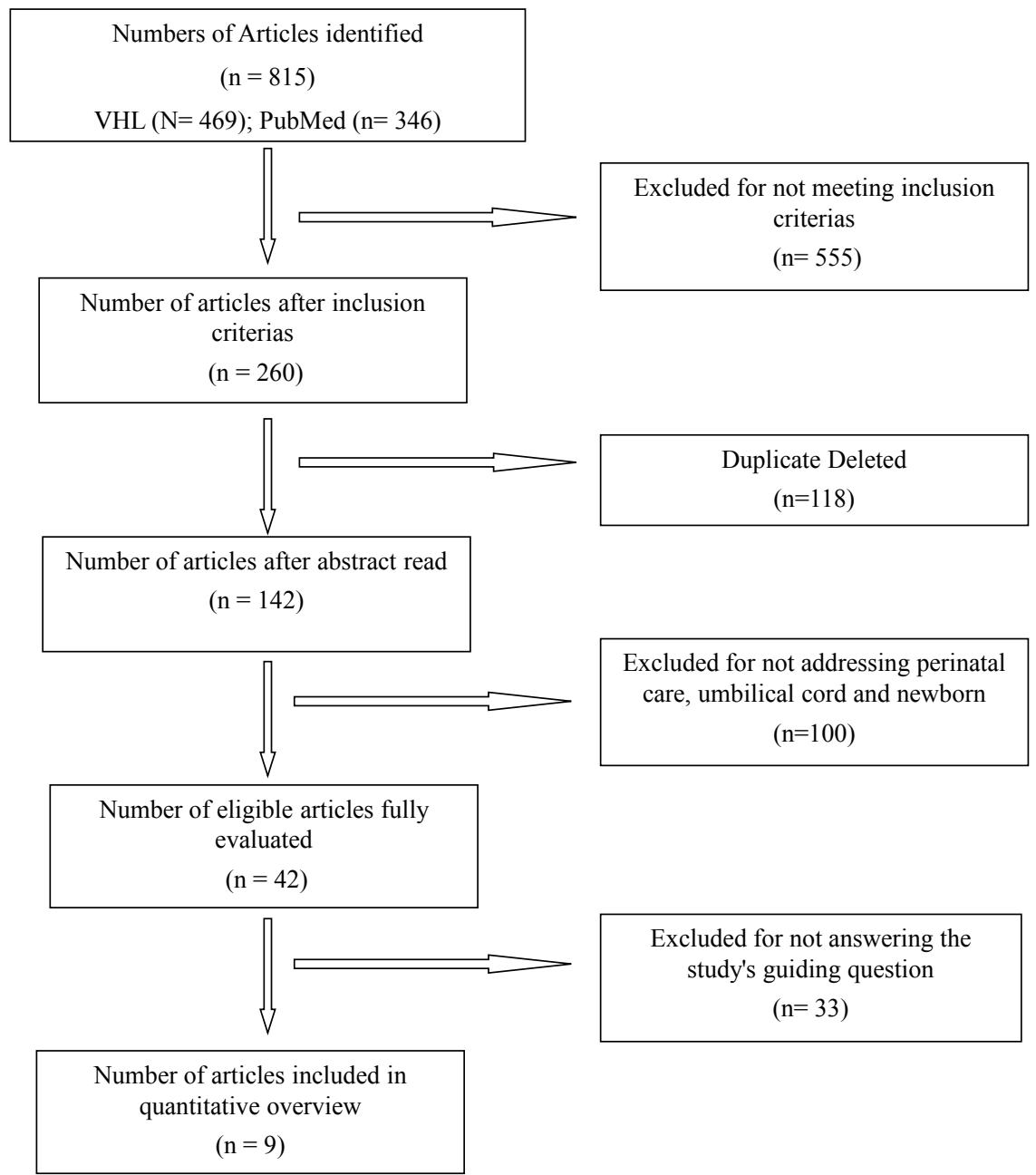

Figure 1. Flowchart of the selection process of articles found and included in the review, in VHL and PubMed/Medline-Goiânia, GO, 2017.

analyzed. In 2015, 2014 and 20132 articles (22.2\%) were published each year respectively, while in 2016, 2012 and 2011 there are only 1 publication each year (11.1\%) (Table 1).

According to the methodology of the selected papers, the types of study were: 2 literature review articles (22.2\%), 3 qualitative research (33.3\%), 1 quantitative research (11.1\%), 1 microanalysis (11.1\%), 1 descriptive cross-sectional (11.1\%) and 1 control case $(11.1 \%)$. There was a predominance of publications in the English language, corresponding to 8 articles (88.8\%) and only 1 article in the Portuguese language (11.1\%).

The publications resulted from different journals being: Global Health Action, Niger J Clin Pract, Pediatr Infect Dis J, Rev Enferm UERJ, Reproductive Health, BMC Pregnancy Childbirth, Jpn J Nurs Sci, BMC Int Health Hum Right and Medicine each with only one publication (11.1\%). Analyzing the study sites 3 articles were performed in England (33.3\%) and the others in other countries such as Brazil, the United States, India, Italy, Japan and Sweden there was only one publication in each (11.1\%). 
Table 1. Search result of the articles selected for sample composition. Study identification by author, title, type of study and journal/year. Goiânia, GO, Brazil, 2017.

\begin{tabular}{|c|c|c|c|}
\hline Author (s)/Journal/Year & Title summarized & Study type & Evidence Level \\
\hline Quattrin R, et al./Medicine/2016 & $\begin{array}{l}70 \% \text { Alcohol Versus Dry Cord Care in the } \\
\text { Umbilical Cord Care }\end{array}$ & Case Control & III-1 \\
\hline Nalwadda CK, et al./Global Health Action/2015 & $\begin{array}{l}\text { Sociocultural beliefs and newborn referral in rural } \\
\text { Uganda }\end{array}$ & Qualitative & III-2 \\
\hline Sacks E, et al./BMC Pregnancy Childbirth/2015 & Practices for neonates in southern, rural Zambia & Qualitative & III-2 \\
\hline $\begin{array}{l}\text { Degefie T, et al./BMC Int Health Hum } \\
\text { Rights/2014 }\end{array}$ & Newborn care interventions in rural Ethiopia & Qualitative & III-2 \\
\hline Salam RA, et al./Reproductive Health/2014 & $\begin{array}{l}\text { Postnatal interventions for improved maternal and } \\
\text { neonatal health }\end{array}$ & Systematic literature review & I \\
\hline Alparslan Ö, Demirel Y/Jpn J Nurs Sci/2013 & Neonatal care practices in Turkey & Descriptive, transverse & VI \\
\hline Karumbi J, et al./Pediatr Infect Dis J/2013 & $\begin{array}{l}\text { Umbilical cord care for prevention of infection and } \\
\text { neonatal mortality }\end{array}$ & Systematic literature review & I \\
\hline $\begin{array}{l}\text { Abhulimhen-Iyoha BI, Ibadin MO/Niger J Clin } \\
\text { Pract./2012 }\end{array}$ & $\begin{array}{l}\text { Umbilical cord care practices among mothers in } \\
\text { Benin City, Nigeria }\end{array}$ & Qualitative & VI \\
\hline Freitas TM, Porto F./Rev Enferm UERJ/2011 & $\begin{array}{l}\text { Care of the newborn's umbilical cord in the 19th } \\
\text { century }\end{array}$ & Microanalysis & VI \\
\hline
\end{tabular}

The studies were also analyzed regarding the research approach and thus classified in the levels of evidence [26]. From the sample 6 articles were evaluated with level of evidence IV and 3 articles with level of evidence III. And from the analysis of the results of the studies, three thematic categories were constituted: Aspects that influence the curative practices of the umbilical stump; Products and techniques used in curative practices of the umbilical stump and their impacts on morbidity and mortality of the umbilical stump; Recommended strategies for best practices in umbilical stump care.

\section{Discussion}

\section{Aspects that influence the healing practices of the umbilical stump}

There were found 4 (50\%) articles that highlighted the aspects that influence the healing practices of the umbilical stump [27] [28] [29] [30]. These studies aimed to know the traditional practices in relation to care with the umbilical stump, to later determine the factors that influence healing practices. Education level is considered one of the most important predictors for curative practices [28]. A study by Alparslan and Demirel (2012) found that the lower the level of education of mothers, the more common are beliefs in care with the umbilical stump. The study also complements that there was no statistically significant difference ( $p>0.05)$ to correlate such practices with women's age [28].

However, a study by Abhulimhen Iyoha and Ibadin (2012) found that older mothers practice more beneficial care compared to younger mothers, perhaps because they have gained experience over time and because younger mothers are more susceptible and consequently more influenced by other caregivers [29]. 
Other studies show that the confidence in the knowledge of other women who have lived the same experiences [such as grandparents, sisters and neighbors] is what determines the practice of the most varied ways possible [31], therefore, the cultural context in which these women are inserted is what determines how she cares for her newborn [6]. In addition, traditional practices are preferred because they have spiritual dimensions, easy availability, appointment as well as lower cost [32].

Thus, some authors cite the need to reconcile family and scientific knowledge, valuing the experiences of women and family members and then reconstructing their knowledge of newborn care [6]; for this, it is necessary to improve the communication between those involved in the process so that behavior change can improve these practices [27].

Products and techniques used in curative practices of the umbilical stump and their impacts on morbidity and mortality of the umbilical stump

There were $6(66.6 \%)$ articles that highlighted this theme and highlighted the most used techniques and products [27] [28] [29] [30] [33]. In 2 articles (25\%), there were reports of traditional care practices, such as abdominal bandage or abdominal band. This care aimed to avoid friction between the umbilical stump and the skin until the navel fell [27] [29]. Another article reported that the use of topical human bed is associated with shorter umbilical cord release time [27] and there is also an indication of dry care use associated with shorter stump fall time [34].

Some studies reveal some harmful practices, such as: coffee, olive oil, burnt black sesame, rotten tree powder [35], green powder or black powder [36], burnt or gray root powder [37], pumpkin flower, cow manure, butter and saliva [38] [39]. Studies also reveal that applying products to the umbilical stump such as ointment, butter, coconut oil, mustard oil, clove oil, turmeric and talc are common practices in many communities [7] [40].

However, Zupan, Garner and Omari (2004) state that, although Kenya is a less economically developed country and where past beliefs from generation to generation are deeply entrenched, the main concern with stump involves the use of alcohol 70\%, denatured or povidone iodine for stump hygiene [41]. In this sense, studies show that the use of topical antimicrobials isolated or associated with dry dressing does not present significant difference in relation to the decrease of infection rates. In addition, in areas with high infection rates, umbilical stump dressing should be performed with $4 \%$ chlorhexidine, as it has the potential to reduce the risk of neonatal sepsis [42] [43].

A study of 29,760 newborns in Bangladesh found that the use of chlorhexidine is effective, but further research is needed regarding the frequency of intervention [44]. However, it is noticeable that the application of chlorhexidine $4 \%$ to the newborn's umbilical stump may reduce the neonatal mortality rate from omphalitis compared to not using it, since the protective effects occur in the first weeks of life, even with a subsequent reduction. Of protection the impact of the measure remains significant during the neonatal period [45] [46]. 
Nonetheless, one study showed that there is no significant difference between keeping the umbilical stump clean without application of any product, leaving it exposed to air (dry care) and the use of solutions. It's relevant to say that the time of detachment of the cord was shorter among individuals who received dry care [34].

The World Health Organization (WHO) since 1998 recommends dry care on the umbilical stump. Cleaning in case of dirt should be done with water only. The use of topical antiseptics, like chlorhexidine, should be recommended in situations where hygiene conditions are poor and/or infection rates are high [4]. Therefore, chlorhexidine has been shown to be an effective, acceptable and inexpensive intervention that can be easily used by health professionals, community and family members [47].

Based on this recommendation, the articles included in this review 5 (55.5\%) indicated chlorhexidine as an effective antiseptic that significantly reduces adverse effects related to umbilical stump infection in potentially contaminated environments; 4 (44.4\%) spoke about dry dressing (also known as dry sec) and 2 $(22.2 \%)$ also talked about the use of alcohol 70\%.

The articles also addressed the association between newborn practices, the occurrence of infections such as tetanus and neonatal mortality [27] [30] [31] [32]. The umbilical stump should be a potential source of contamination, taking into consideration two important factors: natural colonization of the newborn's skin and umbilical cord with potentially pathogenic microorganisms and the application of harmful substances to the umbilical stump [11] [48] [49].

Approximately $40 \%$ of child deaths occur in the first month of life, and one third of these deaths are attributed to infectious processes [3] [50]. Factors contributing to the high incidence of infections and neonatal tetanus in developing countries may be pointed out: unhygienic circumstances and procedures performed by untrained personnel [1], and other harmful practices [48] that can be associated with popular beliefs. A study by Güleç (2000) mentions that traditional applications of substances to the umbilical stump may result in tetanus infection [51]. Other strategies should be considered as important tetanus prevention measures, such as correct hand hygiene to provide care to the newborn and the correct follow-up of the vaccination schedule [29].

From this perspective, a study conducted from November 2002 to March 2005 selected 15,123 children randomly from communities in southern Nepal to be monitored for the presence of omphalitis and umbilical stump fall time. Newborns receive one of the following umbilical stump care: $4 \%$ chlorhexidine cleaning, soap and water cleaning, or dry care. The longest fall time was not associated with the presence of infection. In addition, chlorhexidine $4 \%$ has been recommended for use in environments where the risk of infection is high because it is effective in reducing infection and mortality [43] [52].

So, most often umbilical stump infections can be prevented, so it is necessary to identify best practices in order to reduce neonatal mortality and morbidity rates and offer alternatives to widespread harmful practices [53]. This can and 
should be accomplished through educational interventions.

\section{Best practice strategies for umbilical stump care}

There were found $2(22.2 \%)$ articles whose central theme was to identify practices in the care of the umbilical stump, thus suggesting modifications and strategies to improve survival in the neonatal period [8] [54].

Care of the newborn varies between different cultures and the perception of the disease and care are unique in each context [55]. Understanding local practices and beliefs during a newborn's first month of life is essential for optimizing and promoting care based on healthy behaviors that ensure its survival and continuity [54] [56]. At this moment, the importance of home visit to the postpartum woman as an educational strategy is highlighted [57]. Providing antiseptic kits along with guidance on appropriate practices in umbilical stump care is the most recommended measure in underdeveloped and developing countries for the prevention of umbilical stump infections, as they have a low cost and high acceptability/utilization rate [58].

\section{Conclusions}

From studies that address the evolution of umbilical stump healing practices and their repercussions, it is possible to highlight that most publications occurred in the 21st century, in developed countries and in the English language. And despite the advances made, there is still much work to be done in the search for adequate and quality care for the newborn.

It is concluded that practices that could be considered outdated, such as substance application, band use and heat treatment, are still present in many countries. Therefore, the need for orientation actions for mothers and families about care with the umbilical stump and complications is highlighted, since maternal education is one of the main aspects that influence the improper practices of umbilical stump healing.

This guidance should be provided by a multi-professional team that addresses and encourages women from pregnancy, during antenatal consultations, delivery room and accommodation, with detailed and accessible information on proper care of the newborn and umbilical stump.

With this family preparation by multi-professional teams, it is believed that finally, what is described in the literature can be performed daily. This is by cleaning the umbilical stump with soap and water and then performing antisepsis with $70 \%$ alcohol or chlorhexidine solution in potentially contaminated environments.

\section{Conflicts of Interest}

The authors declare no conflicts of interest regarding the publication of this paper.

\section{References}

[1] Oestergaard, M.Z., Inoue, M., Yoshida, S., Mahanani, W.R., Gore, F.M., Cousens, S., 
et al. (2011) Neonatal Mortality Levels for 193 Countries in 2009 with Trends since 1990: A Systematic Analysis of Progress, Projections, and Priorities. PLOS Medicine, 8, e1001080. https://doi.org/10.1371/journal.pmed.1001080

[2] Black, R.E., Cousens, S., Johnson, H.L., Lawn, J.E., Rudan, I. and Bassani, D.G. (2010) Global, Regional, and National Causes of Child Mortality in 2008: A Systematic Analysis. The Lancet, 375, 1969-1987. https://doi.org/10.1016/S0140-6736(10)60549-1

[3] Blencowe, H., Cousens, S., Mullany, L.C., Lee, A.C.C., Kerber, K., Wall, S., et al. (2011) Clean Birth and Postnatal Care Practices to Reduce Neonatal Deaths from Sepsis and Tetanus: A Systematic Review and Delphi Estimation of Mortality Effect. BMC Public Health, 11, S11. https://doi.org/10.1186/1471-2458-11-S3-S11

[4] World Health Organization (WHO) (1998) Care of the Umbilical Cord. Maternal and New Born Health/Safe Motherhood. World Health Organization, Geneva.

[5] Linhares, E.F. and Da Silva, L.W.S. (2012) The Care of the Newborn's Umbilical Stump from the Point of View of Its Caregivers: Cultural Knowledge. Texto \& Contexto Enfermagem, 21, 828-836. https://doi.org/10.1590/S0104-07072012000400013

[6] Iserhad, A.R., Budó, M.L., Neves, E.T. and Badke, M.R. (2009) High Risk Newborn Mother's Cultural Practices of Caring in Southern Brazil. Escola Anna Nery-Revista de Enfermagem, 13, 116-122. https://doi.org/10.1590/S1414-81452009000100016

[7] Salam, R.A., Mansoor, T., Mallick, D., Lassi, Z.S., Das, J.K. and Bhutta, Z. (2014) Essential Childbirth and Postnatal Interventions for Improved Maternal and Neonatal Health. Reproductive Health, 11, S3.

https://doi.org/10.1186/1742-4755-11-S1-S3

[8] Karumbi, J., Mulaku, M., Aluvaala, J., English, M. and Opiyo, N. (2013) Topical Umbilical Cord Care for Prevention of Infection and Neonatal Mortality. The Pediatric Infectious Disease Journal, 32, 78-83. https://doi.org/10.1097/INF.0b013e3182783dc3

[9] Gomes, A.P., Freitas, B.A., Rodrigues, D.C., Silveira, G.L., Tavares, W.R. and Siqueira-Batista, R. (2011) Clostridium tetani Infections in Newborn Infants: A Tetanus Neonatorum Review. Revista Brasileira de Terapia Intensiva, 23, 484-491. https://doi.org/10.1590/S0103-507X2011000400014

[10] Siqueira-Batista, R., Gomes, A.P., Calixto-Lima, L., Vitorino, R.R., Perez, M.C.A., Mendonça, E.G., et al. (2011) Sepsis: An Update. Revista Brasileira de Terapia Intensiva, 23, 207-216. https://doi.org/10.1590/S0103-507X2011000200014

[11] Mir, F., Tikmani, S.S., Shakoor, S., Warraich, H.J., Sultana, S., Ali, S.A., et al. (2011) Incidence and Etiology of Omphalitis in Pakistan: A Community-Based Cohort Study. Journal of Infection in Developing Countries, 5, 828-833. https://doi.org/10.3855/jidc.1229

[12] Silva, D.M. (2010) Tetanus as a Base Illness for Dysphagia. Revista CEFAC, 12, 499-504. https://doi.org/10.1590/S1516-18462010000300018

[13] Ledermann, W.D. (2011) La alferecía y los primeros casos de tétanos neonatal descritos en Chile en 1894. Revista Chilena de Infectologia, 28, 599-602. https://doi.org/10.4067/S0716-10182011000700016

[14] Chukwuka, J.O., Ezeudu, C.E. and Nnamani, K.O. (2015) Neonatal and Post-Neonatal Tetanus in Nnamdi Azikiwe University Teaching Hospital, Nnewi, South-East, Nigeria: A 10-Year Review. Tropical Journal of Medical Research, 18, 30-33. https://doi.org/10.4103/1119-0388.152552

[15] Costa, D.A., Aguiar, E.D., Coelho, E.P., França, E.L., Ribeiro, L.F. and Mota, Z.S. (2013) Nursing in the Control and Prevention of Neonatal Tetanus: Literature Re- 
view. Revista Contexto e Saúde, 15, 50-61.

[16] Lawn, J., Kerber, K., Enweronu-Laryea, C. and Cousens, S. (2010) 3.6 Million Neonatal Deaths-What Is Progressing and What Is Not. Seminars in Perinatology, 34, 371-386. https://doi.org/10.1053/j.semperi.2010.09.011

[17] Ministério da Saúde. Portal da Saúde SUS. Confirmed Cases of Neonatal Tetanus. Brasil, Grandes Regiões e Unidades Federadas. 1990 a 2011.

[18] Ibrahim, S., Mikayir, G., Yekta, C., Salih, G., Işık, R., Konukoğlu, R., et al. (2011) Skin Burn in Two Term Newborn Due to Use of $70 \%$ Alcohol for Umbilical Care: Case Report. The Journal of Kartal Training and Research Hospital, 22, 75-78. https://doi.org/10.5505/jkartaltr.2011.42275

[19] Linhares, E.F., Martins, L.A. and Dias, J.A. (2014) Educating to Care for the Newborn: Prevention of Omphalitis and Neonatal Tetanus-Experience Report. Revista de Enfermagem UFPE, 8, 2539-2544.

[20] Vieira, L.J., Oliveira, M.H.P. and Lefevre, F. (2006) Use of the Expression "Seven-Day Disease" by Mothers of Children Who Died of Neonatal Tetanus in Minas Gerais (1997-2002). Texto \& Contexto Enfermagem, 15, 51-59. https://doi.org/10.1590/S0104-07072006000100006

[21] Bhutta, Z.A., Das, J.K., Bahl, R., Lawn, J.E., Salam, R.A., Paul, V.K., et al. (2014) Can Available Interventions End Preventable Deaths in Mothers, Newborn Babies, and Stillbirths, and at What Cost? The Lancet, 384, 347-370. https://doi.org/10.1016/S0140-6736(14)60792-3

[22] Corria, T.I. and Pereira, M.L. (2013) The Nursing Care and Consumer Satisfaction during Postpartum. Revista Eletrônica de Enfermagem, 17, 21-30.

[23] Souza, M.T., Silva, M.D. and Carvalho, R. (2010) Integrative Review: What Is It? How to Do It? Einstein (Sao Paulo, Brazi), 8, 102-106. https://doi.org/10.1590/s1679-45082010rw1134

[24] De Sousa, L.D., Lunardi Filho, W.D., Lunardi, V.L., Santos, S.S. and Dos Santos, C.P. (2011) The Nursing Scientific Production about the Clinic: An Integrative Review. Revista da Escola de Enfermagem da USP, 45, 494-500. https://doi.org/10.1590/S0080-62342011000200027

[25] Mendes, K.D.S., Silveira, R.C.C.P. and Galvão, C.M. (2008) Integrative Literature Review: A Research Method to Incorporate Evidence in Health Care and Nursing. Texto \& Contexto Enfermagem, 17, 758-764.

[26] Stetler, C.B., Morsi, D., Rucki, S., Broughton, S., Corrigan, B., Fitzgerald, J., et al. (1998) Utilization-Focused Integrative Reviews in a Nursing Service. Applied Nursing Research, 11, 195-206. https://doi.org/10.1016/S0897-1897(98)80329-7

[27] Sacks, E., Moss, W.J., Winch, P.J., Thuma, P., Dijk, J.H. and Mullany, L.C. (2015) Skin, Thermal and Umbilical Cord Care Practices for Neonates in Southern, Rural Zambia: A Qualitative Study. BMC Pregnancy Childbirth, 15, Article No. 149. https://doi.org/10.1186/s12884-015-0584-2

[28] Alparslan, Ö. and Demirel, Y. (2013) Traditional Neonatal Care Practices in Turkey. Japan Journal of Nursing Science, 10, 47-54. https://doi.org/10.1111/j.1742-7924.2012.00209.x

[29] Abhulimhen-Iyoha, B.I. and Ibadin, M.O. (2012) Determinants of Cord Care Practices among Mothers in Benin City, Edo State, Nigeria. Nigerian Journal of Clinical Practice, 15, 210-213. https://doi.org/10.4103/1119-3077.97320

[30] Degefie, T., Amare, Y. and Mulligan, B. (2014) Local Understandings of Care during Delivery and Postnatal Period to Inform Home Based Package of Newborn Care 
Interventions in Rural Ethiopia: A Qualitative Study. BMC International Health and Human Rights, 14, 17. https://doi.org/10.1186/1472-698X-14-17

[31] Barbosa, M.A., Teixeira, N.Z. and Pereira, W.R. (2007) Dialogue between Nurses and Mothers during the Mother-Child Binominal Consultation. Acta Paulista de Enfermagem, 20, 226-229. https://doi.org/10.1590/S0103-21002007000200018

[32] Özyazıcıoglu, N. (2009) Cultural Perspectives on Child Care. Nursing and Midwifery at the Symposium on Cross-Cultural Perspectives, Çanakkale, 79-83.

[33] Freitas, T.M. and Porto, F. (2011) Care of the Newborn's Umbilical Cord in the 19th Century. Revista Enfermagem UERJ, 19, 524-529.

[34] Quattrin, R., Iacobucci, K., De Tina, A.L., Gallina, L., Pittini, C. and Brusaferro, S. (2016) 70\% Alcohol versus Dry Cord Care in the Umbilical Cord Care. Medicine (Baltimore), 95, e3207. https://doi.org/10.1097/MD.0000000000003207

[35] Çalıskan, D. (2004) Conservation in Developmental Hip Dislocation. Journal of Continuous Medical Education, 13, 190-192.

[36] Lunze, K., Bloom, D.E., Jamison, D.T. and Hamer, D.H. (2013) The Global Burden of Neonatal Hypothermia: Systematic Review of a Major Challenge for Newborn Survival. BMC Medicine, 11, 1741-7015. https://doi.org/10.1186/1741-7015-11-24

[37] World Health Organization (WHO) (2006) Pregnancy, Childbirth, Postpartum and Newborn Care: A Guide for Essential Practice. World Health Organization, Geneva.

[38] Mullany, L.C., Darmstadt, G.L., Katz, J., Khatry, S.K., LeClerg, S.C., Adhikari, R.K., et al. (2007) Risk Factors for Umbilical Cord Infection among Newborns of Southern Nepal. The American Journal of Epidemiology, 165, 203-211. https://doi.org/10.1093/aje/kwj356

[39] Mrisho, M., Schellenberg, J.A., Mushi, A.K., Obrist, B., Mshinda, H., Tanner, M., et al. (2008) Understanding Home-Based Neonatal Care Practice in Rural Southern Tanzania. Transactions of the Royal Society of Tropical Medicine and Hygiene, 102, 669-678. https://doi.org/10.1016/j.trstmh.2008.04.029

[40] Ayaz, A. and Saleem, S. (2010) Neonatal Mortality and Prevalence of Practices for Newborn Care in a Squatter Settlement of Karachi, Pakistan : A Cross-Sectional Study. PLoS ONE, 5, e13783. https://doi.org/10.1371/journal.pone.0013783

[41] Zupan, J., Garner, P. and Omari, A.A. (2004) Topical Umbilical Cord Care at Birth. Cochrane Database of Systematic Reviews, No. 3, CD001057.

https://doi.org/10.1002/14651858.CD001057.pub2

[42] Mullany, L.C., Darmstadt, G.L. and Tielsch, J.M. (2003) Role of Antimicrobial Applications to the Umbilical Cord in Neonates to Prevent Bacterial Colonization and Infection: A Review of the Evidence. The Pediatric Infectious Disease Journal, 22, 996-1002. https://doi.org/10.1097/01.inf.0000095429.97172.48

[43] Mullany, L.C., Darmstadt, G.L., Khatry, S.K., Leclerg, S.C., Katz, J. and Tielsch, J.M. (2006) Impact of Umbilical Cord Cleansing with 4.0\% Chlorhexidine on Time to Cord Separation among Newborns in Southern Nepal: A Cluster-Randomized, Community-Based Trial. Journal of Obstetric, Gynecologic, \& Neonatal Nursing, 35, 123-128. https://doi.org/10.1542/peds.2006-1091

[44] Arifeen, S.E., Mullany, L.C., Shah, R., Mannan, I., Rahman, S.M., Talukder, M.R., Begum, N., Al-Kabir, A., Darmstadt, G.L., Santosham, M., et al. (2012) The Effect of Cord Cleansing with Chlorhexidine on Neonatal Mortality in Rural Bangladesh: A Community-Based, Cluster-Randomised Trial. The Lancet, 379, 1022-1028. https://doi.org/10.1016/S0140-6736(11)61848-5

[45] Imdad, A., Mullany, L.C., Baqui, A.H., Arifeen, S.E., Tielsch, J.M., Khatry, S.K., et 
al. (2013) The Effect of Umbilical Cord Cleansing with Chlorhexidine on Omphalitis and Neonatal Mortality in Community Settings in Developing Countries: A Meta-Analysis. BMC Public Health, 13, S15.

https://doi.org/10.1186/1471-2458-13-S3-S15

[46] Imdad, A., Bautista, R.M., Senen, K.A., Uy, M.E., Mantaring, J.B. and Bhutta, Z.A. (2013) Umbilical Cord Antiseptics for Preventing Sepsis and Death among Newborns. Cochrane Database of Systematic Reviews, No. 5, CD008635. https://doi.org/10.1002/14651858.CD008635.pub2

[47] World Health Organization (WHO), Chlorhexidine Working Group (2012) Chlorhexidine Cord Care: A New, Low-Cost Intervention to Reduce Newborn Mortality. Geneva.

[48] Mullany, L.C., Saha, S.K., Shah, R., Islam, M.S., Rahman, M., Islam, M., et al. (2012) Chlorhexidine Cord Cleansing on the Bacteriologic Profile of the Newborn Umbilical Stump in Rural Sylhet District, Bangladesh: A Community-Based, Cluster-Randomized Trial. The Pediatric Infectious Disease Journal, 31, 444-450. https://doi.org/10.1097/INF.0b013e3182468ff0

[49] Emeribe, V.C. and Akah, L.C. (2011) Neonatal Tetanus in African Children: Causes, Symptoms, Predisposing Factors, Prevention and Control. Arts and Social Sciences Journal, 2011, 21-24.

[50] Moran, A.C., Kerber, K., Sitrin, D., Guenther, T., Morrissey, C.S., Newby, H., et al. (2013) Measuring Coverage in MNCH: Indicators for Global Tracking of Newborn Care. PLOS Medicine, 10, 1-9. https://doi.org/10.1371/journal.pmed.1001415

[51] Güleç, C.A. (2000) Transcultural Perspective to the Disease and Health Concepts in the Anatolian Culture. Journal of Clinical Psychology, 3, 34-39.

[52] World Health Organization (WHO) (2013) Recommendations on Postnatal Care of the Mother and Newborn.

[53] Capurro, H. (2004) Topical Umbilical Cord Care at Birth: RHL Commentary. The WHO Reproductive Health Library.

[54] Nalwadda, C.K., Waiswa, P., Guwatudde, D., Kerber, K., Peterson, S. and Kiguli, J. (2015) As Soon as the Umbilical Cord Gets Off, the Child Ceases to Be Called a Newborn: Sociocultural Beliefs and Newborn Referral in Rural Uganda. Global Health Action. https://doi.org/10.3402/gha.v8.24386

[55] Herlihy, J., Shaikh, A., Mazimba, A., Gagne, N., Grogan, C., Mpamba, C., et al. (2013) Local Perceptions, Cultural Beliefs and Practices That Shape Umbilical Cord Care: A Qualitative Study in Southern Province, Zambia. PLoS ONE, 8, e79191. https://doi.org/10.1371/journal.pone.0079191

[56] Ribeiro, P.T. (2015) Territorial Perspective, Regionalisation and Networks: An Apolitical Approach to Health in the Federative Republic of Brazil. Saúde e Sociedade, 24, 403-412. https://doi.org/10.1590/S0104-12902015000200001

[57] Oliveira, J.F., Quirino, G.S. and Rodrigues, D.P. (2012) Puerperas' Perception Concerning the Care Provided by the Health Team in Pospartum. Revista RENE, 13, 74-84.

[58] Soofi, S., Cousens, S., Imdad, A., Bhutto, N., Ali, N. and Bhutta, Z.A. (2012) Topical Application of Chlorhexidine to Neonatal Umbilical Cords for Prevention of Omphalitis and Neonatal Mortality in a Rural District of Pakistan: A Community-Based, Cluster-Randomised Trial. The Lancet, 379, 1029-1036. https://doi.org/10.1016/S0140-6736(11)61877-1 